\title{
LIMITATIONS OF JET VENTILATION THROUGH THE LARYNGOSCOPE
}

\author{
I. Winerman, S. Ezra, A. Man and S. Segal
}

\begin{abstract}
A series is presented of 100 patients who underwent direct laryngoscopy under general anaesthesia.

Our preferred technique of ventilation is jet insufflation by an injector attached to the blade of the laryngoscope, as it provides the surgeon with a quiet and completely exposed larynx. In nine cases, chest expansion was assessed as inadequate by the anaesthetist. These patients were obese with a short neck, and/or stiff-necked; thus, insertion of the laryngoscope was difficult and a good seal between it and the larynx could not be achieved. Arterial blood gas values in six of these patients demonstrated marked hypoventilation. To improve ventilation in these patients an alternative technique of insufflation through a nasotracheal catheter was used. Arterial blood gas values indicated that this method resolved the problem of hypoventilation. Although the catheter somewhat limits the view of the endolarynx, the improved ventilation outweighs the drawbacks of this technique.

It is suggested that for the obese and/or stiff-necked patient, a nasotracheal catheter be used electively for ventilation.
\end{abstract}

Key Words: ANAesthesia, otolaryngological; ANAesthetic TeChniques, jet ventilation.

IN MICROSURGERY of the larynx by direct laryngoscopy under general anaesthesia, it is mandatory that the larynx be immobile, relaxed and unobstructed.

Methods previously introduced to overcome this difficulty have included apnoeic oxygenation and use of the cuirass ventilator. The first method is unsatisfactory because it unavoidably causes respiratory acidosis, thus imposing a time limit; the second is cumbersome and inefficient.

In 1967 Sanders $^{1}$ described the use of a jet injector to ventilate the lungs during bronchoscopy. This led to the application of jet injector ventilation based on the venturi principle in microlaryngeal operations. Since then, a great variety of non-obstructive techniques have been developed for this procedure. ${ }^{2-4}$

The attachment of the oxygen jet injector to the blade of the laryngoscope as proposed by Oulton and Donald ${ }^{2}$ has the advantage of simplicity of application and affords a completely unobstructed view of the larynx for the surgeon.

I. Winerman, M.D., A. Man, M.D., S. Segal, M.D., Department of Otolaryngology; S. Ezra, M.D., Department of Anaesthesia; Edith Wolfson Hospital, Holon, Israel.

Correspondence: I. Winerman, M.D., Department of Otolaryngology, Edith Wolfson Hospital, Tel Giborim, Holon, Israel.

Can. Anaesth. Soc. J., vol. 29, no. 2, March 1982
On the other hand, critics of this technique have pointed to the potential hazards of hypoventilation due to misplacement of the laryngoscope. . $^{5,6}$ We observed this main disadvantage especially in the obese stiff-necked patient.

In this paper, we present the technique of jet ventilation through a catheter inserted by the nasotracheal route as an alternative in order to overcome the problem of hypoventilation in these problem patients.

\section{Material and Methods}

One hundred unselected patients who underwent either diagnostic or therapeutic direct laryngoscopy between the years 1978 and 1980 were included in the study. Of these, 58 were males. Ages ranged between 17 and 78 years.

The laryngoscopy procedures varied in duration from 25 to 45 minutes.

The patients were given meperidine $50 \mathrm{mg}$ and atropine $0.5 \mathrm{mg}$ one hour before the operation. Induction was with Innovar $2 \mathrm{~mL}$ and thiopentone $400 \mathrm{mg}$. Relaxation was induced with succinylcholine $75 \mathrm{mg}$ and maintained by intermittent injection of $25 \mathrm{mg}$ of the drug; in no case did the total succinylcholine dose exceed $400 \mathrm{mg}$.

After the initial succinylcholine injection the 117 
lungs were ventilated by mask with $100 \%$ oxygen before introduction of the laryngoscope. Upon implacement of the laryngoscope, the venturi needle was connected and jet ventilation was initiated.

Hospital pipeline oxygen at $310 \mathrm{kPa}$ (45p.s.i.) was connected by a high-pressure hose through a manual interruptor to the injector needle attached to the proximal end of the Jako laryngoscope. The needle was a simple 16 SWG needle $7 \mathrm{~cm}$ long. Ventilation was maintained by activating the interruptor intermittently.

Respiration was maintained at a rate of 14 to 20 per minute. Adequacy of ventilation was gauged by observing chest expansion. When difficulties were encountered in placing the laryngoscope or the degree of chest expansion was assessed as inadequate, jet ventilation was continued through a number 16 catheter inserted by the nasotracheal route.

During tissue manipulation and surface suction, ventilation was suspended.

Arterial blood samples were drawn from the radial artery before induction and again 10 minutes after initiation of jet ventilation. In those patients in whom the degree of chest expansion was assessed to be inadequate, a second blood sample was taken before insertion of the nasotracheal catheter and a third after 10 minutes. The syringes were capped and stored in ice, and measurements of $\mathrm{pH}, \mathrm{PCO}_{2}$ and $\mathrm{PO}_{2}$ were done within 30 minutes of sampling.

\section{RESULTS}

Table I summarizes the minimum, maximum, mean and standard values of $\mathrm{PO}_{2}, \mathrm{PCO}_{2}$ and $\mathrm{pH}$ of arterial blood samples obtained from 80 patients before and during ventilation through a jet injector attached to the laryngoscope. Those values obtained from the patients ventilated by the nasotracheal catheter are summarized in Table II.

Significant differences were not noted between the sexes.

There was no correlation between oxygen levels and carbon dioxide levels in either group.

\section{Discussion}

The use of an operating microscope for microsurgery of the larynx requires an anaes-
TABLE I

Arterial Blood Gas Values in 91 Patients Ventilated With Jet INJeCtor AtTACHED to THE LARYNGOSCOPE

\begin{tabular}{ccc}
\hline \hline & $\begin{array}{c}\text { Before } \\
\text { anaesthesia }\end{array}$ & $\begin{array}{c}\text { After 10 min of } \\
\text { anaesthesia }\end{array}$ \\
\hline $\mathrm{Pa}_{\mathrm{O}_{2}}$ Min & 11.70 & 12.24 \\
$(\mathrm{kPa}) \mathrm{Max}$ & 12.90 & 14.89 \\
Mean & 12.16 & 14.13 \\
$\mathrm{S.D}$. & 0.35 & 1.13 \\
$\mathrm{~Pa}_{\mathrm{Co}}$ Min & 4.65 & 5.05 \\
$(\mathrm{kPa})$ Max & 5.98 & 6.52 \\
Mean & 5.32 & 5.89 \\
$\mathrm{~S} . \mathrm{D}$. & 0.36 & 0.44 \\
$\mathrm{pH}$ & 7.36 & 7.35 \\
Max & 7.45 & 7.42 \\
Mean & $7, .40$ & 7.39 \\
S.D. & 0.032 & 0.033 \\
\hline
\end{tabular}

thetic technique which provides the surgeon with an immobile unobstructed larynx.

In an attempt to approach this ideal situation, two basic techniques are currently used. One technique, based on the venturi principle, employs an oxygen jet attached to the blade of the laryngoscope. ${ }^{2-4}$ The resulting high pressure inflates the lungs and, upon interruption of the jet, passive expiration takes place. The second technique is based on the placement of a small nasotracheal catheter ${ }^{6-8}$ or a modified tracheal tube between the vocal cords. ${ }^{9}$ Inflation of the lungs is achieved by an intermittent burst of high-pressure oxygen.

From the endoscopist's viewpoint, the major advantage of ventilation through the laryngoscope by an oxygen jet is complete exposure of the endolarynx without obstruction or distortion. This technique requires a good seal between the laryngoscope and the larynx; failure in this, as observed by Rontal, et al., ${ }^{6}$ leads to the spillage of entrained air into the pharynx and, thus, hypoventilation. Inadequate removal of alveolar carbon dioxide is rapidly reflected in a rise of arterial $\mathrm{PCO}_{2}$ and a decrease in $\mathrm{pH}$, predisposing the myocardium to arrhythmias.

Potential hazards due to misplacement of the laryngoscope were observed especially in the short-necked and/or stiff-necked patients, where insertion of the laryngoscope was complicated and a good seal between it and the larynx was difficult to achieve. In the group of patients observed to have a poor chest expansion when ventilated through the laryngoscope, $\mathrm{Pa}_{\mathrm{CO}_{2}}$ in- 
TABLE II

arterial Blood Gas Values in Nine Patients in Whom Ventilation by Jet Injector was Changed to Ventilation Through Nasotracheal CATHETER

\begin{tabular}{|c|c|c|c|}
\hline & $\begin{array}{c}\text { Before } \\
\text { anaesthesia }\end{array}$ & $\begin{array}{l}\text { Ventilation by } \\
\text { jet injection }\end{array}$ & $\begin{array}{l}\text { After } 10 \mathrm{~min} . \\
\text { ventilation through } \\
\text { N.T. catheter }\end{array}$ \\
\hline $\begin{array}{c}\mathrm{Pa}_{\mathrm{O}_{2}} \text { Min } \\
(\mathrm{kPa}) \\
\text { Max } \\
\text { Mean } \\
\text { S.D. } \\
\mathrm{Pa}_{\mathrm{Co}_{0}} \text { Min } \\
(\mathrm{kPa}) \text { Max } \\
\text { Mean } \\
\\
\text { S.D. } \\
\mathrm{pH} \quad \text { Min } \\
\text { Max } \\
\text { Mean } \\
\text { S.D. }\end{array}$ & $\begin{array}{c}11.57 \\
12.63 \\
12.14 \\
0.33 \\
4.92 \\
6.12 \\
5.45 \\
0.31 \\
7.35 \\
7.43 \\
7.39 \\
0.031\end{array}$ & $\begin{array}{r}6.38 \\
12.64 \\
9.95 \\
2.23 \\
5.32 \\
12.90 \\
9.13 \\
2.72 \\
7.15 \\
7.40 \\
7.26 \\
0.087\end{array}$ & $\begin{array}{l}17.16 \\
28.46 \\
22.05 \\
3.85 \\
4.12 \\
5.91 \\
5.30 \\
0.63 \\
7.35 \\
7.45 \\
7.41 \\
0.032\end{array}$ \\
\hline
\end{tabular}

creased from an average of 5.45 to $9.58 \mathrm{kPa}$. Similarly, the $\mathrm{pH}$ fell from a mean of 7.39 preoperatively to 7.23 . In one extreme case, $\mathrm{Pa}_{\mathrm{CO}_{2}}$ increased to $12.5 \mathrm{kPa}$ and the $\mathrm{pH}$ fell to 7.15 . In these patients ventilation was changed to jet insufflation through a nasotracheal catheter. By using this technique adequate ventilation was achieved and $\mathrm{Pa}_{\mathrm{CO}_{2}}$ decreased to an average of $5.59 \mathrm{kPa}$.

The blood gas values obtained using jet ventilation through the laryngoscope show that hypoventilation may exist to a degree that could be dangerous in the unselected patient and may be a limiting factor in long procedures. Our findings here contrast with the normal values found by Oulton and Donald ${ }^{2}$ and by Lee. ${ }^{3}$ This may be due to differences in technique or because of the small numbers of patients studied by those authors.

The present findings reinforce the importance of preselection of patients for jet ventilation through the laryngoscope blade. In patients with a short and/or stiff neck or when insertion of the laryngoscope proves difficult, inadequate ventilation using this technique should be anticipated. In these cases elective use of the nasotracheal catheter ventilating technique is recommended.

\section{REFERENCES}

1. SANDERS, R.D. Two ventilating attachments for bronchoscopes. Delaware M.J., 39: 170 (1967).

2. OUlTon, J.L. \& DonaLD, O.M. A ventilating laryngoscope. Anesthesiology 35: 540 (1971).

3. LEE, S.T. A ventilating laryngoscope for inhalation anaesthesia and augmented ventilation during laryngoscopic procedures. Brit. Jour. Anaes. 44: 874 (1972)

4. Rajagopalan, R., Smith, F. \& RamachanDRAM, P.R. Anesthesia for microlaryngoscopy and definitive surgery. Can. Anaesth. Soc. J. 19: 83 (1972).

5. El-Naggar, M. Keh, E., Stemmers, A. \& Col.LINS, V.J. Jet ventilation for microlaryngoscopic procedures: A further simplified technic. Anes. Anal. 53: 797 (1974).

6. Rontal, M., Rontal, E. \& Wenokum, M. Jet insufflation anesthesia for endolaryngeal surgery. Laryngoscope 90: 1162 (1980).

7. Spoerel, W.E. \& Greenway, R.E. Technique of ventilation during endolaryngeal surgery under general anaesthesia. Can. Anaesth. Soc. J. 20: 369 (1973).

8. Pybus, D.A., O'Connors, A.F. \& Henville, J.D. Anesthesia for laryngoscopy: A technique using the nuffield anaesthetic ventilator. Brit. Jour. Anaes. 50: 501 (1978).

9. Carden, E. \& Crutchfield, W. Anaesthesia for microsurgery of the larynx (A new method). Can. Anaesth. Soc. J. 20: 378 (1973).

\section{RÉSUMÉ}

L'étude a porté sur un groupe de cent patients qui subissaient une laryngoscopie directe sous anesthésie générale avec ventilation par injecteur. La technique de choix des investigateurs consistait à l'insufflation périodique par injecteur fixé à la lame de laryngoscope, ce qui permet une exposition complète du larynx. Dans quinze cas, l'expansion thoracique a été 
jugée insuffisante par l'anesthésiste. Les patients en cause étaient obèses, avaient le cou court et pouvaient souffrir de rigidité cervicale de sorte que l'introduction du laryngoscope était difficile et qu'il était impossible de juxtaposer adéquatement le laryngoscope au larynx. De ces six malades l'hypoventilation importante a été démontrée par la détérioration des valeurs gazométriques. Pour améliorer la ventilation dans ces cas, une méthode alternative d'insufflation par canule nasotrachéale avait été prévue et cette méthode a corrigé l'hypoventilation comme l'a démontré la gazométrie. Bien que le cathéter limite quelque peu la vision de l'endolarynx, l'amélioration de la ventilation compense pour cet inconvénient.

Les auteurs suggèrent d'utiliser le cathéter naso-trachéal pour la ventilation par injection chez le patient obèse avec ou sans rigidité de la colonne cervicale. 